\title{
A Highly Sensitive Electrochemical Glucose Sensor By Nickel-Epoxy Electrode With Non-Enzymatic Sensor
}

\author{
${ }^{1 *}$ Riyanto \\ ${ }^{1}$ Department of Chemistry, Faculty of Mathematics and Natural Sciences, \\ Islamic University of Indonesia, Yogyakarta \\ *Email: riyanto@uii.ac.id
}

\begin{abstract}
ABSTRAK
Pembuatan sensor baru untuk analisis glukosa berbasis non enzim glukosa oksidase telah berhasil dilakukan. Elektroda nikel-epoksi dipreparasi dengan cara memotong nikel yang berbentuk plat dengan panjang $1 \mathrm{~cm}$ dan lebar $1 \mathrm{~mm}$, kemudian dihubungan dengan kawat perak dan perekat silver conductive paint. Bagian yang tidak diinginkan ditutup dengan epoksi. Hasil penelitian menunjukkan bahwa elektroda nikel epoksi dalam larutan glukosa dan elektrolit $0,1 \mathrm{M} \mathrm{NaOH}$ menghasilkan $\mathrm{R}^{2}=0,9984$. Nilai LOD, LOQ dan \% perolehan kembali masing-masing sebesar 4,4 $\mu \mathrm{M}, 1,48 \mu \mathrm{M}$ dan 98,19\%. Elektroda nikel-epoksi menunjukkan kemampuan elektrooksidasi yang baik dalam mengoksidasi glukosa dalam larutan alkali. Elektroda nikel epoksi berdasarkan parameter elektrokimia menunjukkan hasil yang sensitive, range linieritas yang lebar, limit deteksi yang baik, selektifitas tinggi dan stabil. Elektroda nikel-epoksi sangat sesuai sebagai elektroda untuk membuat sensor glukosa non enzim dengan keuntungan biaya rendah, pembuatan mudah dan hasil uji yang memuaskan.
\end{abstract}

Kata Kunci: glukosa, sensor, nikel, epoksi, non enzim

\section{ABSTRACT}

The preparation of new sensor for glucose was based on the fact that glucose can be determined by non-enzymatic glucose oxidase. The Ni metals $(99.98 \%$ purity, $0.5 \mathrm{~mm}$ thick, Aldrich Chemical

Company) was used to prepare Ni-Epoxy electrode. The Ni-epoxy electrodes were prepared in square cut of $1 \mathrm{~cm}$ and $1 \mathrm{~mm}$ by length and wide respectively. The Ni metal electrodes were connected to silver wire with silver conducting paint prior covered with epoxy gum. The prepared of nickel-epoxy modified electrode showed outstanding electro catalytic activity toward the oxidation of glucose in alkaline solution. The result from this research are correlation of determination using Nickel-Epoxy electrode for electroanalysis of glucose in $\mathrm{NaOH}$ was $\mathrm{R}^{2}=0.9984$. LOQ, LOD and recovery of the Nickel-Epoxy electrode towards glucose were found to be $4.4 \mu M, 1.48 \mu M$ and $98.19 \%$, respectively.

The Nickel-Epoxy wire based electrochemical glucose sensor demonstrates good sensitivity, wide

linear range, outstanding detection limit, attractive selectivity, good reproducibility, high stability as well as prominent feasibility use of non-enzymatic sensor for monitoring glucose in human urine owing to its advantages of low cost, simple preparation and excellent properties for glucose detection.

Keywords: glucose, sensor, nickel-epoxy, non-enzymatic

Introduction

The detection of glucose is an important issue, because of the clinical significance of measuring human urine glucose (Wang, 2008). Thus, diabetics need a tight monitoring of their human urines glucose levels. Because the diabetes mellitus becomes a more 
serious health problem in recent years, glucose has been recognized as one of the most commonly tested analytes. Enzymatic glucose sensor, based on an enzyme electrode immobilized with glucose oxidase (GOx), has been proposed to measure the urine glucose level for several decades (Shervedani et al., 2004 and Yang et al., 2002).

Development of the glucose sensors has attracted extensive attentions due to their applications in biological systems, food analysis, clinical detections and environmental monitoring (Newman and Turner, 2005) where the merits as high sensitivity, fast response, good stability and low cost have been considered.

Enzymatic sensors from several disadvantages such as poor stability, high cost of enzymes, critical operational conditions and complicated immobilization procedure (Shervedani and Mehrjadi, 2007). Furthermore, instability of the enzyme molecules, originated from various environmental factors such as temperature, $\mathrm{pH}$, humidity, or their inherent properties can influence the sensitivity, selectivity and reproducibility of these electrode (Chung et al., 2006 and Turner and Wilson, 1992).

In terms of non-enzymatic glucose sensors, electrochemical biosensors normally are more reliable, highly sensitive, low cost, and easier to operate compared to other detection schemes such as colorimetry, fluorescent, electrochemical, and optical methods. In particular, graphene/metal oxides (e.g., nickel or cobalt oxides) nanocomposites, which show excellent electrocatalytic activities during glucose detection, have drawn considerable research and development attentions (Veeramani et al., 2015).

\section{Experimental}

\section{Solutions}

All solutions were prepared by dissolving their analytical grade reagent (Merck) in deionised distilled water. D-Glucose $\mathrm{NaOH}$, and buffer phosphate was used as the supporting electrolyte. Buffer phosphate solution was prepared using $0.1 \mathrm{M} \mathrm{KH}_{2} \mathrm{PO}_{4}$ (Merck) and $0.1 \mathrm{M} \mathrm{NaOH}$ (Merck).

\section{Preparation of Nickel-Epoxy Electrode}

Cyclic Voltammetric (CV) analysis was performed with PGSTAT 100 N 100 V/250 mA (Metrohm Autolab). The three electrode system consisted of a nickelepoxy electrode as working electrode, platinum wire as auxiliary electrode and an $\mathrm{Ag} / \mathrm{AgCl}$ (saturated $\mathrm{KCl}$ ) or $\mathrm{SCE}$ electrode as the reference electrode against which all potentials were measured. Electrochemical measurements were carried out at room temperature with a scan rate of $30 \mathrm{mVs}^{-1}$. 


\section{Calibration and validation method}

Calibration curves were obtained

by plotting anodic peak height (current) versus acetaminophen concentration. Validation parameters including linearity, limit of detection (LOD), limit of quantification (LOQ), precision and accuracy were assessed. Cyclic voltammograms (CVs) of acetaminophen solutions were recorded in a wide range of concentrations $(1.0,3.0,5.0,7.0$, and 9.0 $\mathrm{mM}$ ) in $0.1 \mathrm{M} \mathrm{NaOH}$ solution at room temperature.

\section{Result and Discussion}

\section{Electrocatalytic oxidation of glucose at} the Nickel-Epoxy electrode

The electrocatalytic activity of Nickel-Epoxy electrode toward oxidation of glucose is investigated in $0.1 \mathrm{M}$ $\mathrm{NaOH}$ solution by using cyclic voltammetry. As shown in Fig. 1, in the absence of glucose (curve a), a well-defined redox wave with sharp peaks is observed. Upon the addition of $1.0 \mathrm{mM}$ glucose into the $\mathrm{NaOH}$ test solution, the anodic peak current is increased significantly and its potential is shifted to more positive direction, while the cathodic peak current is decreased slightly without significant shift in its potential (curves b). This behavior indicates an irreversible electrochemical process related to the oxidation of glucose. The electrocatalytic oxidation mechanism of glucose at the nickel electrode surface may be simply described by the following reactions (Peng et al., 2012):

$\mathrm{Ni}(\mathrm{OH})_{2}+\mathrm{OH}^{-} \mathrm{NiO} \rightarrow(\mathrm{OH})+\mathrm{H}_{2} \mathrm{O}+\mathrm{e}^{-}$

$\mathrm{NiO}(\mathrm{OH})+$ glucose $\rightarrow \mathrm{Ni}(\mathrm{OH})_{2}+$ gluconolactone

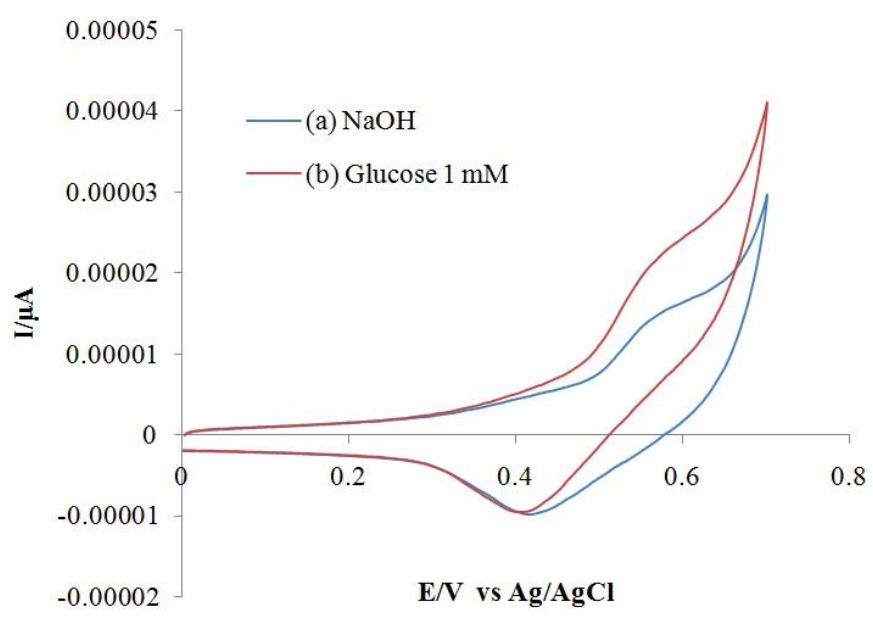

Figure 1. Cyclic voltammogram of (a) $0.1 \mathrm{M} \mathrm{NaOH}$ (without glucose), (b) $0.1 \mathrm{M} \mathrm{NaOH}+$ glucose $1 \mathrm{mM}$ glucose at scan rate $30 \mathrm{mVs}^{-1}$ 

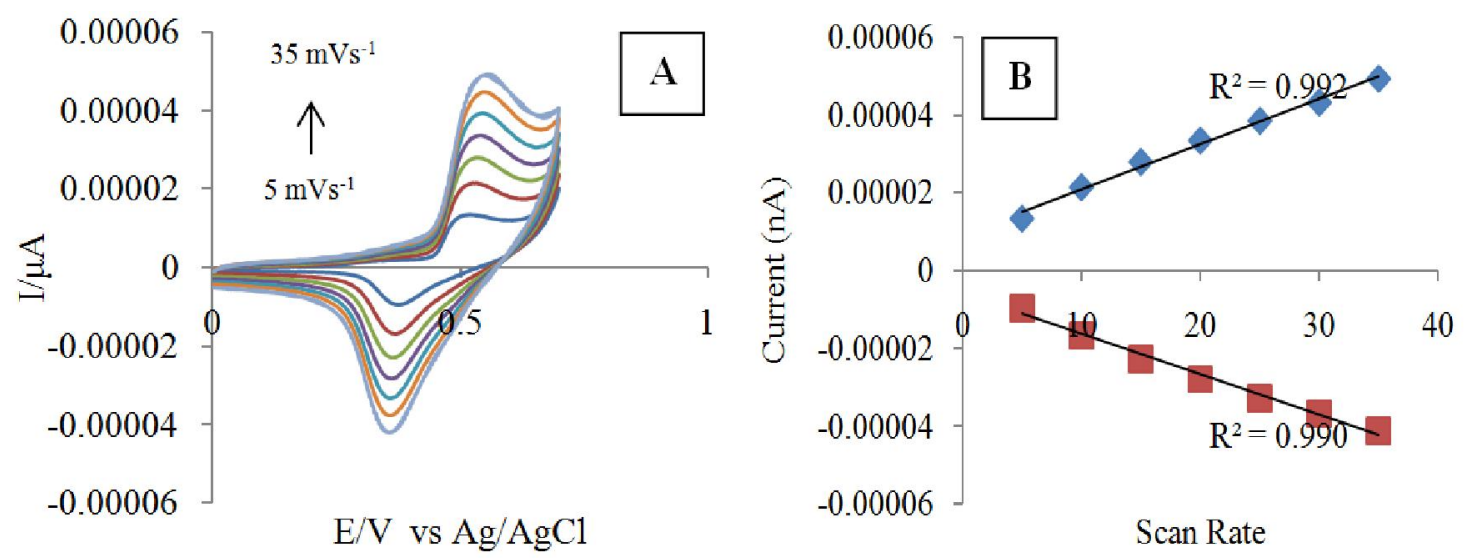

Figure 2. Cyclic Voltammogram of (A). Ni electrode in $0.1 \mathrm{~mol} \mathrm{~L}^{-1} \mathrm{NaOH}$ potensial scan rates from $5-35 \mathrm{mVs}^{-1}$ (B). Calibration curve of $0.1 \mathrm{M} \mathrm{NaOH}$ with various scan rates

The cyclic voltammograms obtained on the Nickel-Epoxy electrode in $0.1 \mathrm{M} \mathrm{NaOH}$ solution at different scan rates are presented in Fig. 2A. Both anodic and cathodic peak currents increase as a function of scan rate. Since no electroactive species exists in the solution phase for this potential window, the observed currents are related to the confined redox reaction of $\mathrm{Ni}(\mathrm{III}) / \mathrm{Ni}(\mathrm{II})$. Implying that the reaction is under diffusion control of $\mathrm{OH}^{-}$from solution phase $(\mathrm{Nie}$ et al. 2011).

$\mathrm{NiO}(\mathrm{OH})+\mathrm{H}_{2} \mathrm{O}+\mathrm{e}^{-} \rightarrow \mathrm{Ni}(\mathrm{OH})_{2}+\mathrm{OH}^{-}$
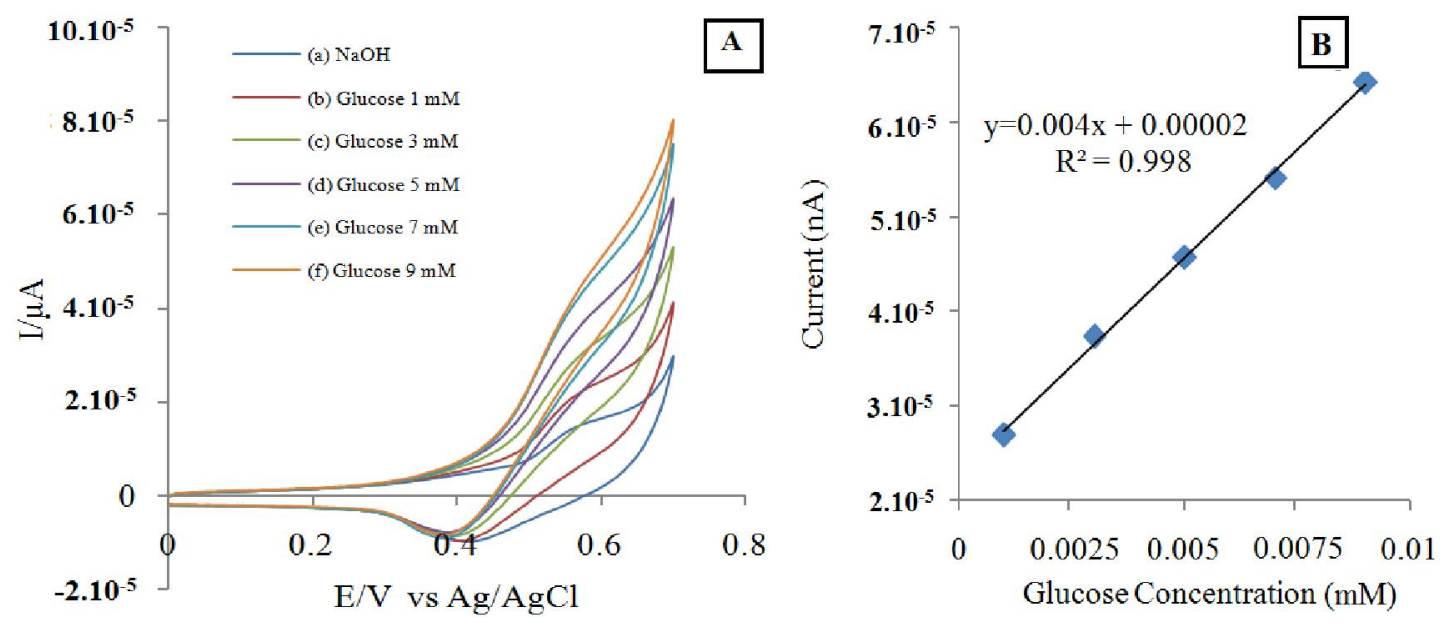

Figure 3. (A). Cyclic voltammogram and (B). Calibration curve of various concentration of glucose at Ni-Epoxy electrode in $0.1 \mathrm{M} \mathrm{NaOH}$ solution ([Glucose]: (a) 0, (b) 1.0, (c) 3.0, (d) 5.0, (e) 7.0, (f) $9.0 \mathrm{mM}$ ), at a scan rate $30 \mathrm{mVs}^{-1}$ 
Fig. 3A shows $\mathrm{CV}$ curves of the Nickel-epoxy electrode measured in $0.1 \quad \mathrm{M} \quad \mathrm{NaOH}$ solution containing various concentrations of glucose, i.e., $0,1.0,3.0,5.0,7.0$ and $9.0 \mathrm{mM}$, at a scan rate of $30 \mathrm{mV} / \mathrm{s}$. It can be seen that there are one anodic peak and one cathodic peaks in the background $\mathrm{CV}$ curve measured before glucose addition; this $\mathrm{CV}$ characterization is consistent with that of the last cycle $\mathrm{CV}$ curve shown in Fig. 3A. The anodic peak corresponds to the oxidation from $\beta$ $\mathrm{Ni}(\mathrm{OH})_{2}$ to $\beta-\mathrm{NiOOH}$, and the cathodic peaks correspond to the reduction from $\beta-\mathrm{NiOOH}$ to $\beta-\mathrm{Ni}(\mathrm{OH})_{2}$, the reduction from $\gamma-\mathrm{NiOOH}$ to $\beta-\mathrm{Ni}(\mathrm{OH})_{2}$, and the reduction from $\gamma-\mathrm{NiOOH}$ to $\alpha-\mathrm{Ni}(\mathrm{OH})_{2}$. After the addition of glucose, a remarkable increase in the anodic peak current density can be observed in the corresponding $\mathrm{CV}$ curve, with reference to the anodic peak current density of the background $\mathrm{CV}$ curve obtained before glucose addition.

The dramatic increase in indicates that the $\mathrm{Ni}(\mathrm{OH})_{2}$ Nickel-epoxy electrode shows an excellent electrocatalytic ability toward glucose this high catalytic activity may be attributed to both the excellent catalytic property of Nickel-epoxy. The apparent and linear increase at the applied potential of about $0.63 \mathrm{~V}$ (vs. $\mathrm{Ag} / \mathrm{AgCl} / \mathrm{KCl}$ sat'd) indicates that the Nickel-epoxy electrode can be used for the glucose sensor with high sensitivity and excellent linearity.

From the calibration curve obtained using Nickel-Epoxy electrode, the correlation of determination $\left(\mathrm{R}^{2}\right)$ recorded is 0.9984. Linear regression equation (Fig. 3B) is $\mathrm{y}=0.0046 \mathrm{x}+2 \cdot 10^{-5}$. The linear regression equation can be used to determine the concentration of glucose in human urine sample.

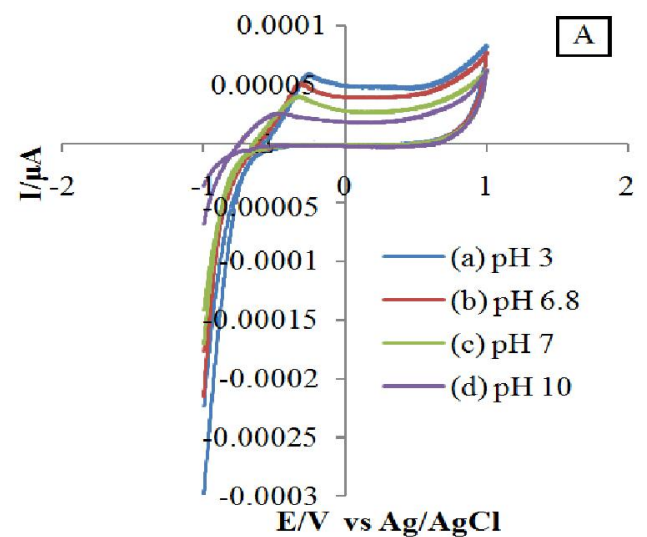

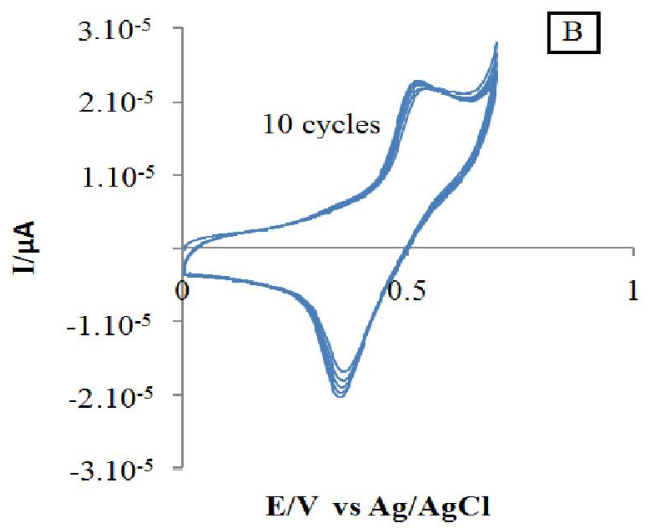

Figure 4. (A). Cyclic voltammogram of $3.0 \mathrm{mM}$ glucose in buffer phosphate solution with vaious pH solutions: (a) 3, (b) 6.8, (c) 7, (d) 10 (B). Cyclic voltammogram of $3 \mathrm{mM}$ glucose in $0.1 \mathrm{M} \mathrm{NaOH}$ solution with 10 cycles and scan rate $30 \mathrm{mVs}^{-1}$ 
The effect of buffer capacity, we reformulated the results presented in Figure $4 \mathrm{~A}$, by presenting the $\mathrm{pH}$ variation at a given glucose concentration. The cyclic voltammograms decreases with the increase of phosphate concentration in the buffer solution. With the increase of buffer capacity, more protons will be neutralized by the phosphate present in the buffer and the transducer (the NickelEpoxy electrode) will sense a smaller $\mathrm{pH}$ variation (Pisoshi et al., 2007).

Table 1. Comparisons of analytical technique for determination of glucose using electrode

\begin{tabular}{cccc}
\hline Electrode $^{\text {a }}$ & Technique Analysis & LOD $(\boldsymbol{\mu M})$ & Reference \\
\hline Ni-Co/rGO & Amperometry & 3.79 & Wang et al., 2013 \\
\hline Ni/indium tin oxide & Amperometry & 0.50 & Tian et al., 2013 \\
\hline NiO-Ag nanofiber & Amperometry & 1.37 & Ding et al., 2010 \\
\hline Ni-MWCNT & Amperometry & 0.89 & Sun et al., 2012 \\
\hline Ni-Epoxy electrode & CV & 4.44 & This work \\
\hline $\begin{array}{l}\text { abbreviations: } \text { rGO, reduced graphene oxide; MWCNT, multi-walled carbon nanotube; CV, } \\
\text { Cyclic voltammetry }\end{array}$ & & &
\end{tabular}

Table 2 Determination of glucose in human urine

\begin{tabular}{lccc}
\hline Sample & Glucose added $(\mathrm{mM})$ & Founded $(\mathrm{mM})$ & Recovery $(\%)$ \\
\hline Human urine & - & 2.67 & - \\
Sample 1 & 3.00 & 2.76 & 92.16 \\
Sample 2 & 5.00 & 5.09 & 101.80 \\
Sample 3 & 7.00 & 7.04 & 100.62 \\
\hline
\end{tabular}

\section{Application for real samples}

Determination of the glucose in human urine samples is also performed on the Nickel-Epoxy electrode by utilizing the calibration curve method. Briefly, the human urine samples of healthy human are first diluted with the $0.1 \mathrm{M} \mathrm{NaOH}$, and added by glucose standar with spike solution than tested by using the Nickel-Epoxy electrode to monitor its glucose content. The results listed in Table 2 reveal that the NickelEpoxy electrode can be used for determination of glucose in human urine samples with favorable accuracy and precision. LOD and LOQ of the electrode towards glucose were found to be $4.4 \mu \mathrm{M}$ and $1.48 \mu \mathrm{M}$, respectively. A comparison of the response characteristics of different modified electrode towards the detection of glucose is tabulated in Table 1 .

\section{Conclusion}

A novel electrochemical nonenzymatic sensor for sensitive and selective detection of glucose was developed based on the Nickel-Epoxy 
electrode. Nickel-Epoxy electrode exhibited excellent electrocatalytic activity toward glucose oxidation, and it could be developed into a highly desirable nonenzymatic glucose sensor, associated with satisfying sensitivity, selectivity and stability. The correlation of determination using Nickel-Epoxy electrode for electroanalysis of glucose was $\mathrm{R}^{2}=0.9984$. LOQ, LOD and recovery of the Nickel-Epoxy electrode towards glucose were found to be $4.4 \mu \mathrm{M}$ and $1.48 \mu \mathrm{M}$ and $98.19 \%$, respectively.

\section{Acknowledgements}

This research was supported by Ministry of Research and Technology and Higher Education, Republic of Indonesia through "Insentif Riset Sinas, Insentif Riset Terapan (RT2015- 0057)".

\section{References}

Chung, T.D. Park, S. and Boo, H., 2006, Electrochemical non-enzymatic glucose sensors, Anal. Chim. Acta, 556, 46-57.

Ding, Y. Wang, Y. Su, L. Zhang, H. and Lei, Y., 2010, Preparation and characterization of $\mathrm{NiO}-\mathrm{Ag}$ Nanofibers, $\mathrm{NiO}$ nanofibers, and porous Ag: towards the developmentof a highly sensitive and selective non-enzymatic glucose sensor, J. Mater. Chem. 20, 9918-9926.

Newman, J.D. and Turner, A.P.F., 2005, Home blood glucose biosensors: a commercial per-spective, Biosens. Bioelectron. 20, 2435 2453.
Nie, H.G. Yao, Z. Zhou, X.M. Yang, Z. and Huang, S.M., 2011, Nonenzymatic electrochemical detection of glucose using welldistributed nickel nanoparticles on straight multi-walled carbon nanotubes, Biosens. Bioelectron. $30,28-34$.

Peng, X. Yu, S.J. Cao, G.Z. Zhou, M. Qiao, L. Yao, J.Y. and He, H.C., 2012, Ni nanoparticles decorated titania nanotube arrays as efficient nonenzymatic glucose sensor, Electrochim. Acta, 76, 512-517.

Pisoshi, A.M., Danet, A.F., and Negulscu, G.P., 2007, Influense of the buffer capacity on glucose potentiometric determination in synthetic solutions and in real sampels with different acidities, Pro. Rom, Acad., Series $B, 75-81$.

Shervedani, R.K. Motahareh. K. Akbar. A and Prickly, 2014, Nickel nanowires grown on $\mathrm{Cu}$ substrate as a supersensitive enzyme-free electrochemical glucose sensor, Sensor and actuator B: Chemical, 204, 783-790.

Shervedani, R.K. Mehrjardi, A.H., 2007, Electrochemical characterization of directly immobilized glucose oxidase on gold mercaptosuccinic anhydride self-assembled monolayer, Sens. Actuators B 126, 415-423.

Sun, A. Zheng, J. and Sheng, Q., 2012, A highly sensitive non-enzymatic glucose sensor based on nickel and multi-walled carbon nanotubes nanohybrid filmsfabricated by one-step coelectrodeposition in ionic liquids, Electrochim. Acta, 65, 64-69.

Tian, H. Jia, M. Zhang, M. and Hu, J., 2013, Nonenzymatic glucose sensor based on nickel ion 
implanted-modified indium tin oxide electrode, Electrochim. Acta. 96, 285-290.

Turner, A.P.F. and Wilson, R. 1992, Glucose oxidase: an ideal enzyme, Biosens. Bioelectron. 7, 165-185.

Veeramani,V., Madhua,R., Chena,S.M., ,Veerakumar,P., Hungb, C.T, and Liub, S.B., 2015, Heteroatomenriched porous carbon/nickel oxide nanocomposites as enzymefree highly sensitive sensors for detection of glucose, Sensor and Actuators: B, 1384-1390

Wang, J., 2008, Electrochemical glucose biosensors, Chem. Rev. 108, 814825.

Wang, L. Lu, X. Ye, Y. Sun, L. and Song Y., 2013, Nickel-cobalt nanostructures coated reduced graphene oxide nanocomposite electrode for nonenzymatic glucose biosensing, Electrochim. Acta 114, 484-493.

Yang. H., Chung. T.D. Kim, Y.T. Choi, C.A. Jun, C.H. and Kim, H.C. 2002, Glucose sensor using a microfabricated electrode and electropolymerized bilayer films, Biosens, Bioelectron, 17, 251-259. 